\title{
TREND ANALYSIS IN RELATIVE HUMIDITY OF DUHOK PROVINCE OF IRAQ
}

\author{
DIYAR AHMAD BLEEJ \\ Dept. of Physics, Faculty of Science, University of Zakho, Kurdistan Region-Iraq
}

(Received: September 18, 2019; Accepted for Publication: February 9, 2020)

\begin{abstract}
Studding the trend analysis in climatic variables and evaluating their statistical significance in recent times are the great evidence of climate change availability. In this study, Parametric linear regression and nonparametric Mann-Kendall test were employed for detecting the seasonal and annual trends in Relative Humidity (RH) time series at seven stations in Duhok province in Kurdistan region of Iraq. The annual RH results indicate a decreasing trend at all stations except Duhok station, whereas the significance trend was observed at Mangesh station by (-0.144 \%/year). The seasonal analysis shows a significant decreasing trend in RH at Akre and Amedy stations during summer season, the trends was negative at most of stations. The parametric and nonparametric results were identical at most stations especially at Duhok station, which is the annual value increased by $(0.07 \% /$ year $)$.
\end{abstract}

KEY WORDS: Relative Humidity, Time Series, Mann-Kendall, Sens Slope, Duhok https://doi.org/10.26682/sjuod.2020.23.1.1

\section{INTRODUCTION}

A global warming results from increasing atmospheric greenhouse gases is high possibility to have an effect upon the hydrological cycle (IPCC 2007). Changes in atmospheric humidity are the key to understand the dynamical and radiative aspects of climate change (Held \& Soden, 2000). The earth's water vapor is an important climatological and meteorological parameter that identifies the earth's weather and climate, due to its role as a greenhouse gas and on account of the large quantity of energy concerned as water changes between the solid, liquid and gaseous (vapor) phases, regardless of its account only $1 / 10,000^{\text {th }}$ of total hydrological cycle's water amount (AbuTaleb et al. 2007). The Tropospheric water vapor comes from earth's surface evaporation and transpiration by plants, while in stratosphere; it comes from the breakdown of methane by sunlight. The atmospheric water vapor amount is prospect to increase under conditions of greenhouse gas induced warming (Willet et al. 2007).

Temperature and absolute water vapor increases with increasing the greenhouse gases, which is affected from increasing the population, industry, factories, Cars, Electric generators etc. in recent years, the population of Duhok province are increased heavily, this increasing in population leads to provide greenhouse gases, which is attributed to the global warming.

Relative humidity (RH) represents the ratio of water vapor partial pressure present in the air to the saturation vapor pressure of water at that temperature, which is strongly affecting the formation of clouds, smog and fog, also it influences on atmospheric visibility (Elliott \& Angell 1997). Furthermore, humidity determines the geographical distribution, maximum intensity of precipitations (Willet et al. 2007), effects on human comfort (Changnon et al. 2003) and has influential implications for investigations including human heat stress (Souch \& Grimmond, 2004). Humidity, both absolute and relative, has possibility to be a very prevision tool for climate research (Abdulwahab, 2015).

Relative humidity depends on temperature and amount of absolute water vapor. Examining and studding long-term trends in hydro climatic variables and evaluating their statistical importance are elementary tools in the disclosure of climate change (Huth and Pokorna 2004). Many studies throughout the world have been 
done on the variability and effects of climate change (Zhang et al. 2009, Liu et al. 2011), while the number of studies that have been carried out to examine the trends of $\mathrm{RH}$ and dew point temperature are few compared to precipitation and air temperature. The increasing pattern of RH has been observed through the most parts in world (Gaffan \& Ross, 1999, vanWijngaarden \&Vincent, 2003, Abu-Taleb et al. 2007, Kousari \& Zarch, 2010) and others. (Talaee et al. 2012) concluded that the annual relative humidity and temperature are increased by $1.03 \% /$ decade and $0.28{ }^{\circ} \mathrm{C} /$ decade respectively in the southern and northern coastal parts of Iran.

In Iraq, (Abdulwahab, 2005) recorded a notable decreasing in RH trends at most parts of Iraq, especially in the northern parts. To the best of our knowledge there is no internationally published works on $\mathrm{RH}$ changes over the past century in north provinces of Iraq including Duhok province. Because of the effect of RH on climate change, Spatial and temporal RH variations has to be regularly and accurately studied for meteorological and climatological purposes (F. Alshawaf et al). Therefore, the aim of this work is to study the temporal variation of relative humidity on the annual and seasonal scales at 7 stations of Duhok province in
Kurdistan region of Iraq, which to the best of our knowledge this is the first study in the region.

\section{STUDY AREA AND DATA}

The area under study is Duhok province which is located in the northern Iraq and lie between latitude $36^{\circ}-38^{\circ} \mathrm{N}$ and longitudes $42^{\circ}$ $45^{\circ}$ E. Turkey is in the north, Syria from the west. In general, Iraq is closes to the water bodies, this water bodies have impact in Iraq's climate, where the Arabian Gulf and Mediterranean Sea are the most effective water bodies in Provinces of Iraq, including Duhok (Al-Timimi \& Al-Khudhairy, 2018). The climate of the study area has an extreme continental climate hot in summer and bitterly cold in winter. Figure (1) shows the location of all meteorological stations in Duhok province, the selected stations have been chosen depending on the availability of the long-term data. In this study, Surface relative humidity data, Duhok Map and other meteorological elements were obtained from the Duhok Directorate of Meteorology and Seismology. The observed data was different for each station, which depends on the history of station. Figure (1) and table (1), illustrates the selected weather stations in study area with geographical coordinates.

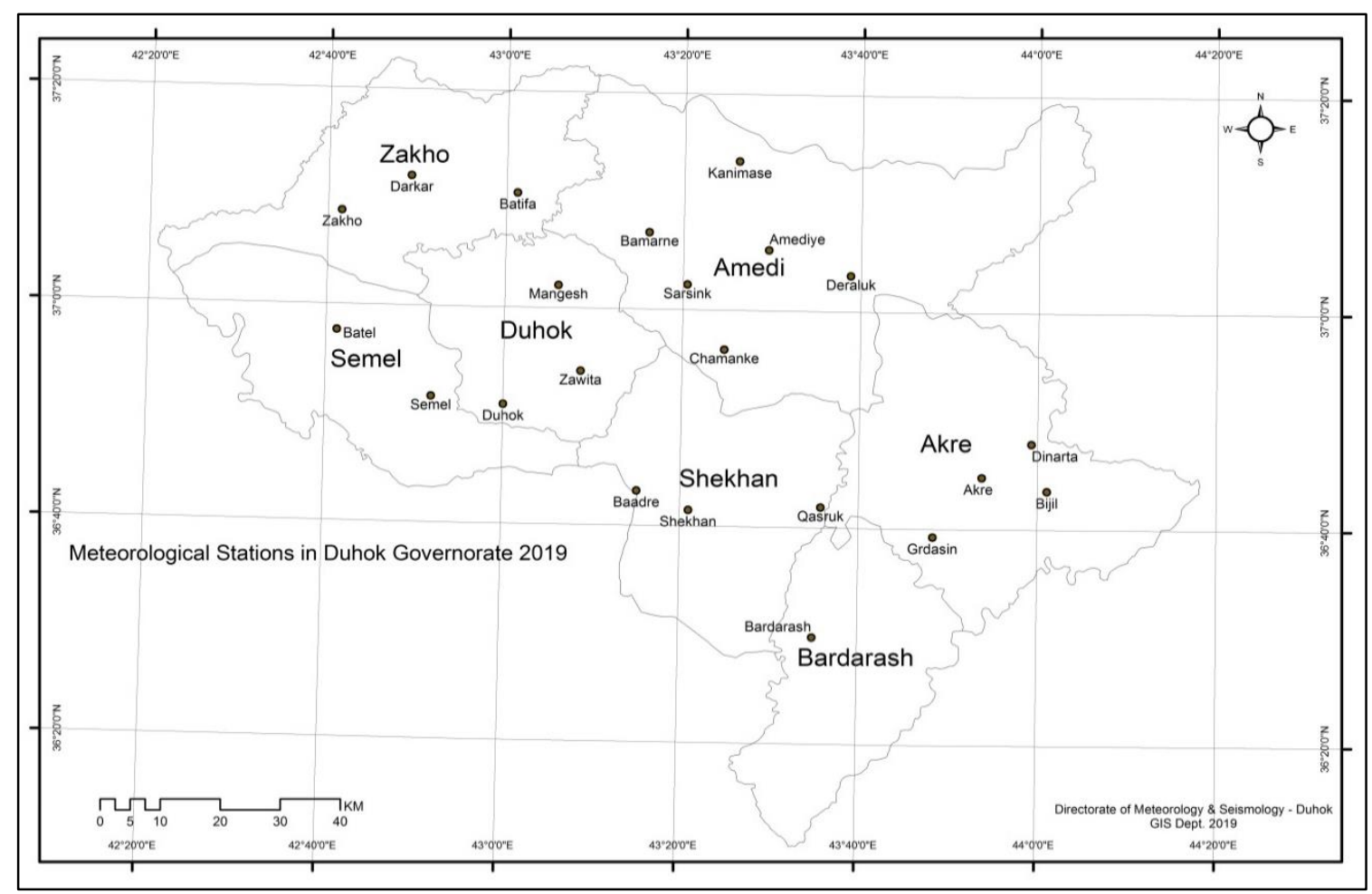

Fig. (1): Selected weather stations in Duhok province 
Table (1): The selected meteorological stations in study area

\begin{tabular}{ccccc}
\hline Weather station & Latitude (North) & Longitude (East) & Elevation (m) & $\begin{array}{c}\text { Years of } \\
\text { observation }\end{array}$ \\
\hline Duhok & $36^{\circ} 50^{\prime}$ & $43^{\circ} 02^{\prime}$ & 583.0 & 27 \\
\hline Zakho & $37^{\circ} 08^{\prime}$ & $42^{\circ} 41^{\prime}$ & 433.8 & 39 \\
\hline Semel & $36^{\circ} 50^{\prime}$ & $43^{\circ} 20^{\prime}$ & 870.0 & 14 \\
\hline Zawite & $36^{\circ} 54^{\prime}$ & $43^{\circ} 09 \mathrm{gv}^{\prime}$ & 890.0 & 17 \\
\hline Mangesh & $37^{\circ} 02^{\prime}$ & $43^{\circ} 06^{\prime}$ & 957.0 & 18 \\
\hline Amedy & $37^{\circ} 05^{\prime}$ & $43^{\circ} 29^{\prime}$ & 1202.0 & 14 \\
\hline Akre & $36^{\circ} 43^{\prime}$ & $43^{\circ} 51^{\prime}$ & 636.0 & 14 \\
\hline
\end{tabular}

Zakho and Duhok stations have the longest period of data recording because they are the oldest stations in study area; the missing data are estimated and filled using different methods for estimating missing data (Y. Xia et al. 1999). The annual and seasonal $\mathrm{RH}$ are presented in table (2)

Table 2- Descriptive statistics for annual and seasonal RH

\begin{tabular}{ccccccccccc}
\hline \multirow{2}{*}{ Station } & \multicolumn{2}{c}{ Summer } & \multicolumn{2}{c}{ Autumn } & \multicolumn{2}{c}{ Winter } & \multicolumn{2}{c}{ Spring } & \multicolumn{2}{c}{ Annual } \\
\cline { 2 - 11 } & Mean & CV & Mean & CV & Mean & CV & Mean & CV & Mean & CV \\
\hline Duhok & 48 & 18 & 21 & 15 & 37 & 11 & 61 & 13 & 41 & 14 \\
\hline Zakho & 51 & 18 & 28 & 17 & 42 & 10 & 65 & 13 & 47 & 10 \\
\hline Semel & 51 & 10 & 22 & 12 & 41 & 11 & 69 & 15 & 46 & 11 \\
\hline Zawite & 53 & 11 & 35 & 14 & 49 & 10 & 62 & 8 & 50 & 12 \\
\hline Mangesh & 54 & 14 & 28 & 7 & 46 & 5 & 65 & 6 & 48 & 12 \\
\hline Amedy & 48 & 17 & 24 & 13 & 47 & 10 & 62 & 14 & 44 & 17 \\
\hline Akre & 49 & 31 & 19 & 19 & 36 & 17 & 64 & 9 & 42 & 15 \\
\hline
\end{tabular}

\section{MATERIALS AND METHODS}

There are several methods for estimating the trend in time series, these methods can be nonparametric or parametric, nonparametric and parametric methods are widely used in hydro climatic variables (Tabari et al., 2011; Abdulwahab, 2015) and others. Parametric trend tests are more powerful than the nonparametric ones when the data are independent, normally distributed and have equal variance (Hamed and Rao 1998). On the other hand, the parametric methods cannot discard outliers properly. While, the nonparametric methods do not rely on data distribution methods, can deal with missing data values and more resistant to outliers (Wilcox 1998). The main disadvantage of the nonparametric methods is that they are fraught with more uncertainty in the statistical estimates compared with the parametric method.

According to the above-mentioned disadvantages and advantages, the parametric linear regression and nonparametric Mann-
Kendall methods have been used. Linear regression and nonparametric Mann-Kendall test (Mann, 1945; Kendall, 1975) with Sen's slope estimation (Sen, 1968) were employed in the RH time scales of annual and seasonal. The excel template MAKESENSE (Salmi et al., 2002) was used to detect trends using MK test and Sen's method used for estimating the trend slope. SPSS software and excel program were applied for linear regression method.

The Mann-Kendall statistic of a series $R_{1}, R_{2}, \ldots ., R_{n}$ is given by:

$$
\mathrm{Z}=\left\{\begin{array}{lll}
\frac{s-1}{\sigma} & \text { if } & S>0 \\
0 & \text { if } & S=0 \\
\frac{s+1}{\sigma} & \text { if } & S<0
\end{array}\right.
$$

In which $\sigma^{2}$ is the variance of $S$ statistic is given by:

$$
\begin{gathered}
\sigma^{2}=\frac{n(n-1)(2 n+5)-\sum t_{i\left(t_{i}-1\right)\left(2 t_{i}+5\right)}}{S=\sum_{j=1}^{n-1} \sum_{k=j+1}^{n} \operatorname{sgn}\left(R_{k}-R_{j}\right)}
\end{gathered}
$$


Where $t_{i}$ represents the number of ties to extent $\mathrm{i}, \mathrm{n}$ is the length of data, $\mathrm{R}_{\mathrm{j}}$ and $\mathrm{R}_{\mathrm{k}}$ are sequential annual values in years $\mathrm{j}$ and $\mathrm{k}$, respectively whereas $\mathrm{j}>\mathrm{k}$, and

$$
\operatorname{sgn}\left(x_{j}-x_{k}\right)= \begin{cases}1 & \text { if } R_{j}-R_{k}>0 \\ 0 & \text { if } R_{j}-R_{k}=0 \\ -1 & \text { if } R_{j}-R_{k}<0\end{cases}
$$

The hypothesis of no trend is rejected if $|Z|$ $>\left|\mathrm{Z}_{1-\alpha / 2}\right|$, where $\mathrm{Z}$ is a measure of significance of trend, and $\alpha$ is a degree of significance.

The nonparametric Sen's slope technique was applied to estimate the scale of trend in the time series, the slope (Ri) of all data pairs is computed as:

$$
R_{i}=\frac{x_{j}-x_{k}}{j-k}
$$

Where $x_{j}$ and $x_{k}$ are the data values at time $j$ and $k$ respectively. The positive and negative values of Qi represent increasing and decreasing trends in the time series.

$$
Q_{i}= \begin{cases}\frac{R_{(N+1)}}{2} & \text { if } \mathrm{N} \text { is odd } \\ \frac{1}{2}\left(R_{N / 2}+R_{(N+2) / 2}\right) & \text { if } \mathrm{N} \text { is even }\end{cases}
$$

\section{RESULTS AND DISCUSSION}

The parametric linear Regression method and non-parametric Mann-Kendal test results on the seasonal and annual values of $\mathrm{RH}$ time series are discussed in this section. Figures (2) and (3) show the seasonal and annual RH series for Duhok and Zakho stations, the increasing and decreasing trends are observed in Zakho station while in Duhok station the trends are positive for both annual and seasonal series.
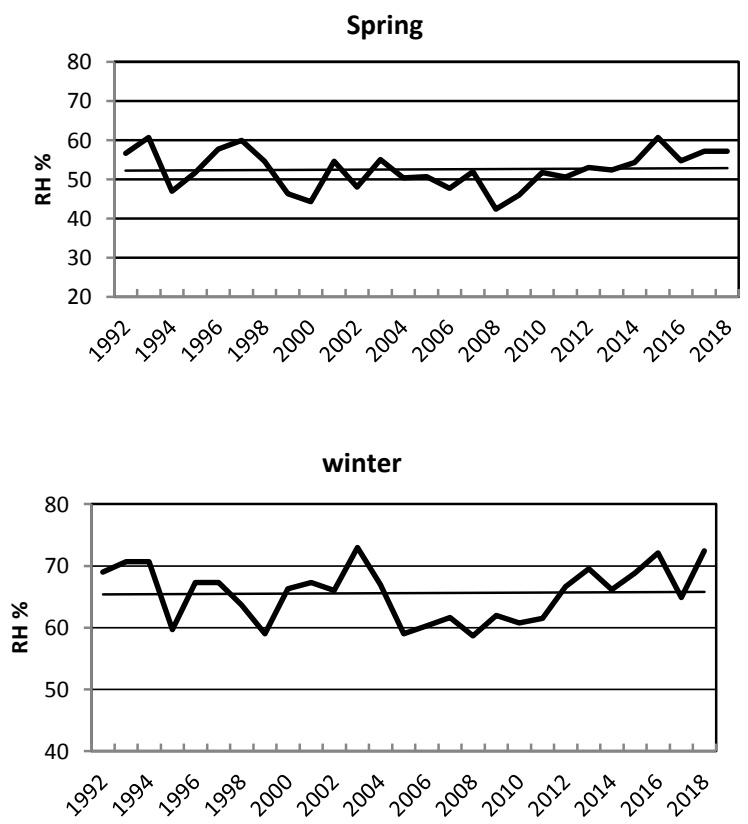

Annual

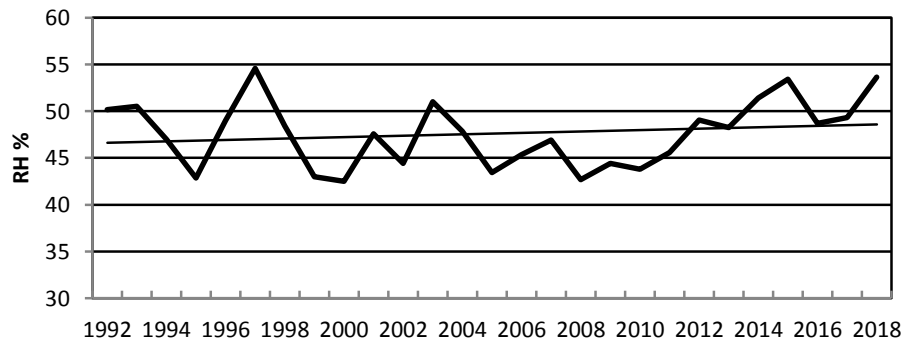

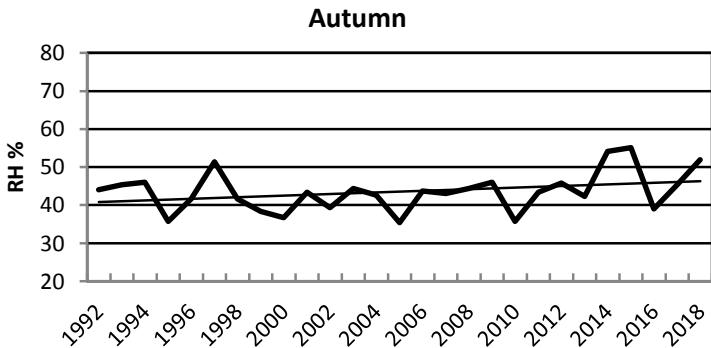

Summer

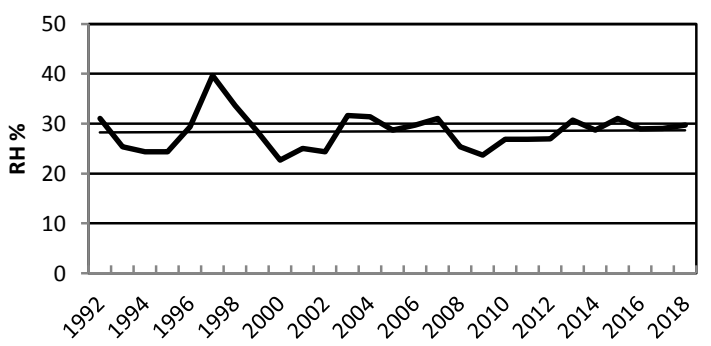


Fig. (2): Time series and trend line of Annual and seasonal RH at Duhok Station.
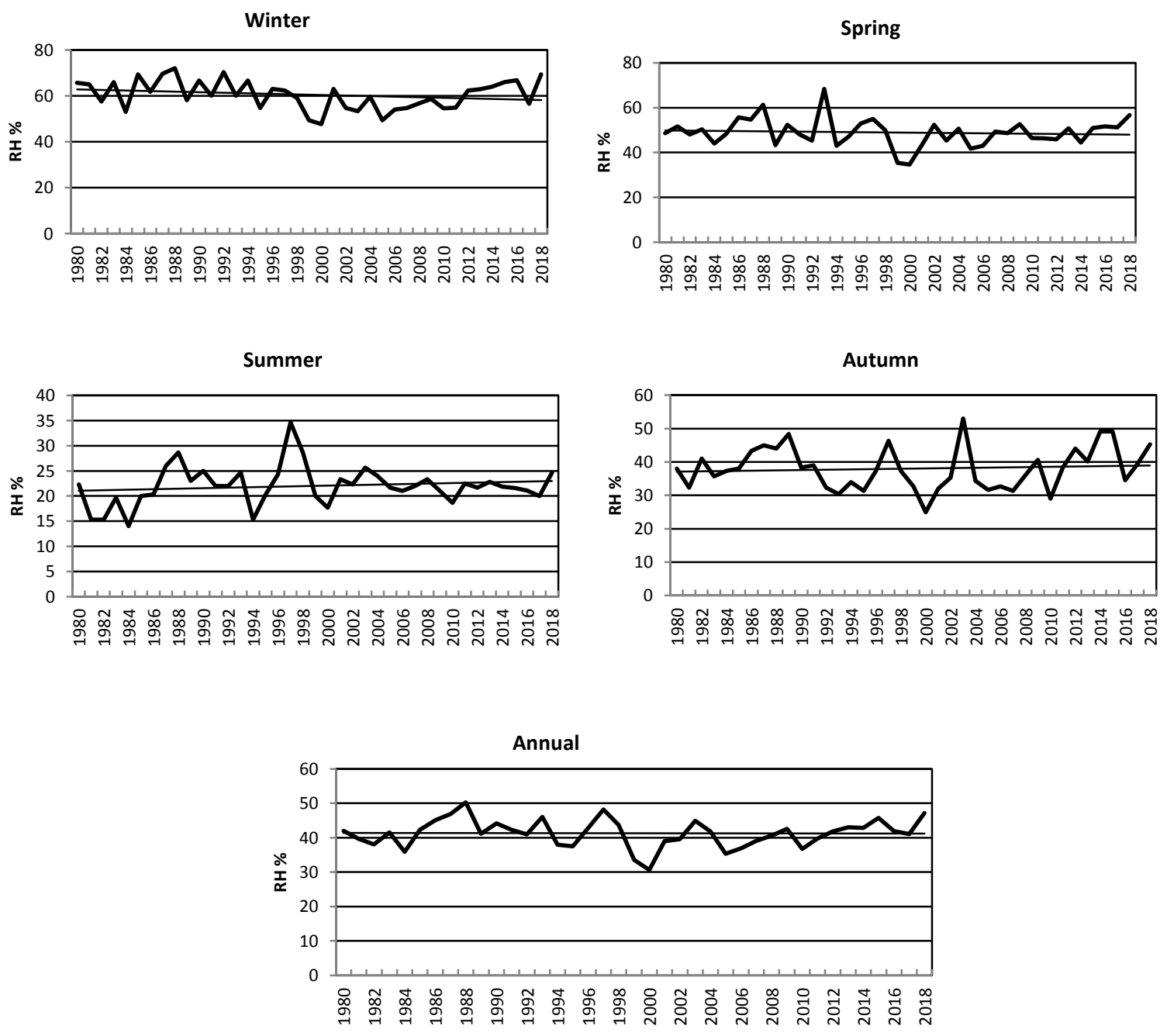

Fig. (3): Time series and trend line of Annual and seasonal RH at Zakho Station.

The results of Mann-Kendal test are illustrated in table (3) and figure (4). The Sens slope estimate was used to obtain the trend slopes for seasonal and annual RH series. Table (3) exhibits the values of trend (present per year) for each station. The annual $\mathrm{RH}$ has been found to be increased only at Duhok station, the center of Duhok Province, which is due to upward trends in all seasons, this increasing may be due to increasing in temperature (combined effect of humidity and air temperature), which mean increasing in humidity and air temperature together, it will effect on human health and comfort. According to other stations, it can be observed that there is a decreasing trend in RH, where none of them are statistically significant, except that of Mangesh station.
Similar to the annual $\mathrm{RH}$ results, the seasonal RH has negative trends at most of stations. In the spring series, the trends of all stations are not statistically significant which has the lowest value of RH at Akre station ($0.7 \%$ /year), while Mangesh station has the height level of RH $(0.114 \%$ /year $)$, this because Mangesh station is near to agricultural areas, which is more humidity than land areas. The summer RH has been found to be decreased in five stations, the decreasing trends were significant at Akre and Amedy stations which are (-0.895\%/year) and (-0.661\%/year) respectively, while in Zakho and Duhok stations, the trends were positive and not significant statistically. 
Table (3): Annual and seasonal results of Mann-Kendall test for RH

\begin{tabular}{|c|c|c|c|c|c|c|c|c|c|c|}
\hline & \multicolumn{2}{|c|}{ Spring } & \multicolumn{2}{|c|}{ Summer } & \multicolumn{2}{|c|}{ Autumn } & \multicolumn{2}{|c|}{ Winter } & \multicolumn{2}{|c|}{ Annual } \\
\hline & Z & $\begin{array}{c}\mathrm{Q} \\
\text { (\%/year) }\end{array}$ & z & $\begin{array}{c}Q \\
\text { (\%/year } \\
\text { ) }\end{array}$ & Z & $\begin{array}{c}\mathrm{Q} \\
\text { (\%/year) }\end{array}$ & Z & $\begin{array}{c}\mathrm{Q} \\
\text { (\%/year) }\end{array}$ & Z & $\begin{array}{c}Q \\
\text { (\%/year) }\end{array}$ \\
\hline Duhok & 0.56 & 0.082 & 0.98 & 0.088 & 1.44 & 0.167 & -0.02 & 0.000 & 1.06 & 0.078 \\
\hline Zakho & -0.22 & -0.026 & 0.45 & 0.026 & 0.44 & 0.033 & -0.94 & -0.105 & -0.04 & -0.005 \\
\hline Akre & -1.56 & -0.700 & $-2.65^{\star *}$ & -0.895 & -1.56 & -0.828 & -1.56 & -0.922 & -1.25 & -0.630 \\
\hline Amedy & -0.82 & -0.380 & $-3.18^{* *}$ & -0.661 & -1.20 & -0.500 & -0.89 & -0.486 & -1.09 & -0.501 \\
\hline Mangesh & 1.17 & 0.114 & -1.43 & -0.313 & 0.00 & 0.000 & -0.36 & -0.148 & $-2.1^{*}$ & -0.144 \\
\hline Semel & 0.00 & 0.021 & -0.69 & -0.531 & -0.89 & -0.465 & 0.89 & 0.488 & -0.75 & -0.371 \\
\hline Zawite & -0.62 & -0.251 & -0.33 & -0.032 & 0.87 & 0.268 & 0.45 & 0.137 & -0.04 & -0.003 \\
\hline
\end{tabular}
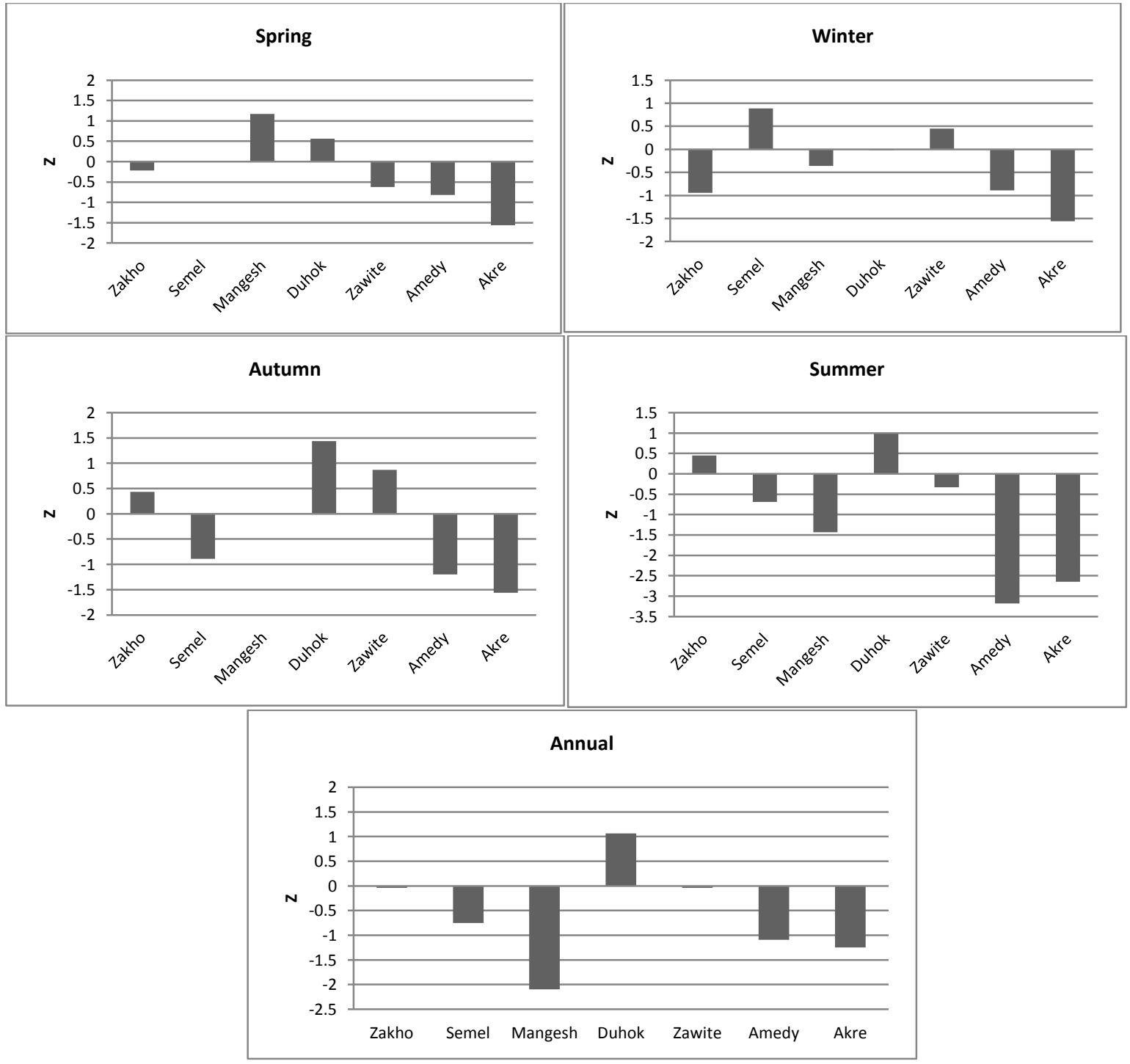

Fig. (4): Annually and seasonally Man-Kendall test results for RH 
Figures 5(a) and 5(b) shows the seasonal comparism profile for Zakho and Dohuk stations respectively, which are represent the multi time series for all seasons, it's clear that Winter season has the highest value of RH then Spring, Summer and Autumn have lower RH value for both stations.

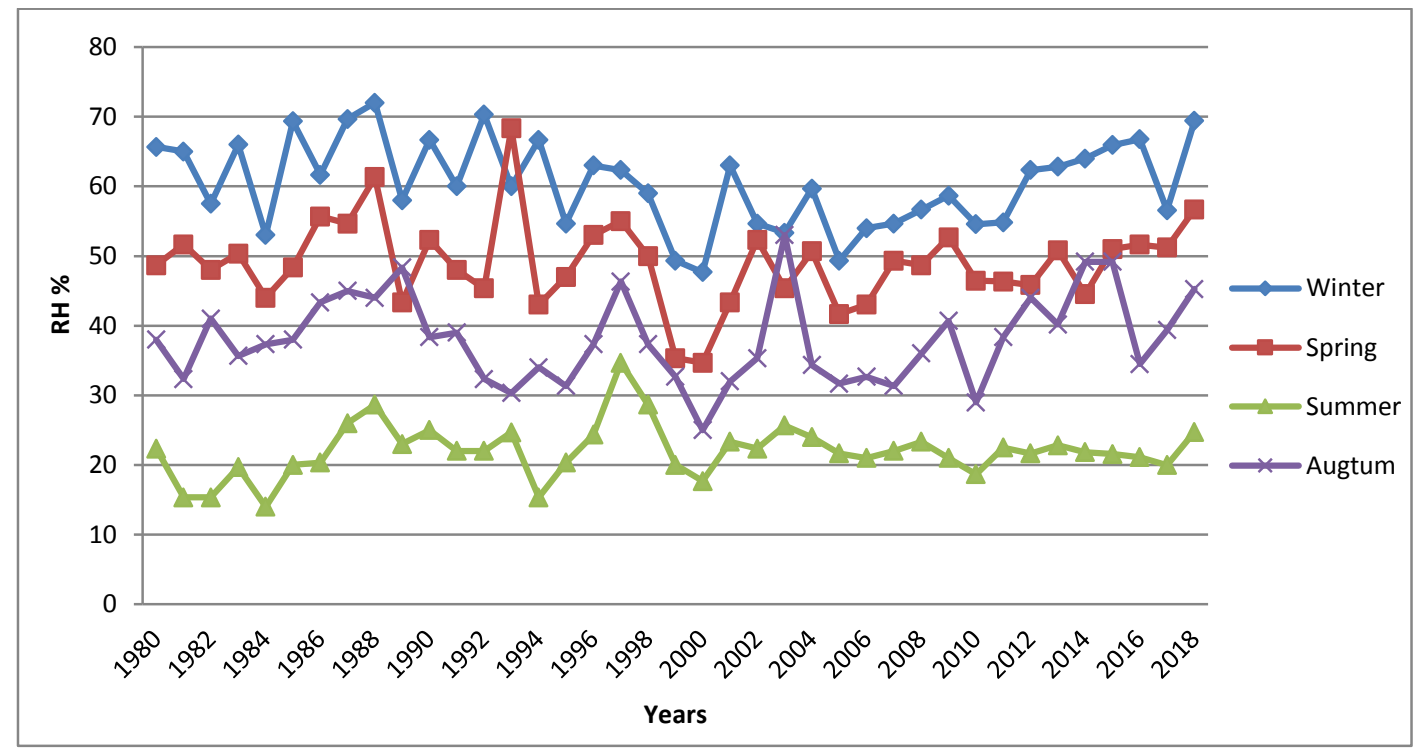

(a)

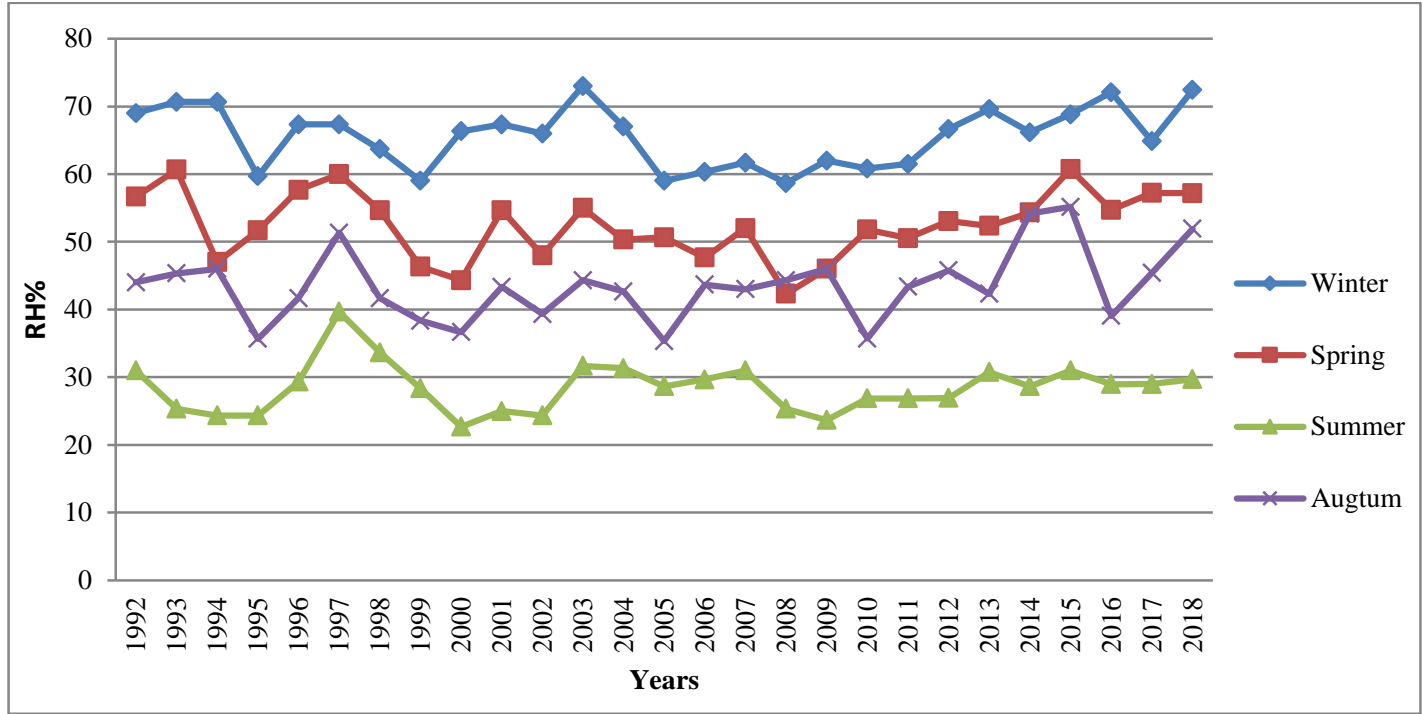

(b)

Fig. 5(a, b): Seasonal variation of RH for Zakho and Dohuk stations

Table (4) illustrated the trend slop and correlation coefficient for annual and seasonal $\mathrm{RH}$ series were obtained using parametric linear regression method. The results are so close to the results of Mann-Kendall test. Duhok station has positive trends in annual and seasonal series; this increasing may be due to the existence of Duhok Dam in the area near the station. The annual series evidence the negative trends in all station, excepting Duhok and Zawite stations, the lowest trend is recorded at Akre station (-0.873\%/year). The spring series has the positive and negative trends, the highest trend is at Mangesh station $(0.16 \% / y e a r)$ and the maximum negative trend at Akre station (-0.888 \%/year) with good correlation coefficient (0.664). Similar to annual series, the summer station has negative trends in all stations, except Duhok and Zakho stations, the minimum value recorded at Akre station ($0.924 \% / y e a r)$ with high correlation coefficient. 
Autumn and winter series are characterized by negative and positive trends, from table its shown that the correlation is greater than 0.2 in most of stations specially at Akre station which have $(-0.915 \% /$ year $)$ in winter season and (-
$0.766 \% / y e a r)$ in Autumn season. The values of correlation coefficient for number of stations are less than 0.2. This low correlation suggests that there is a small significant change in $\mathrm{RH}$ over this

area

Table (4): The values of correlation coefficient $R$ with statistics $b$ (degree centigrade per year) of linear regression method for seasonal and annual series.

\begin{tabular}{|c|c|c|c|c|c|c|c|c|c|c|}
\hline & \multicolumn{2}{|c|}{ Spring } & \multicolumn{2}{|c|}{ Summer } & \multicolumn{2}{|c|}{ Autumn } & \multicolumn{2}{|c|}{ Winter } & \multicolumn{2}{|c|}{ Annual } \\
\hline & $\mathrm{R}$ & $\begin{array}{c}\text { b } \\
(\% / \text { year } \\
\text { ) }\end{array}$ & $\mathrm{R}$ & $\begin{array}{c}b \\
\text { (\%/year) }\end{array}$ & $\mathrm{R}$ & $\begin{array}{c}b \\
(\% / \text { year } \\
\text { ) }\end{array}$ & $\mathrm{R}$ & $\begin{array}{c}\mathrm{b} \\
\text { (\%/year) }\end{array}$ & $\mathrm{R}$ & $\begin{array}{c}\mathrm{b} \\
\text { (\%/year) }\end{array}$ \\
\hline Duhok & 0.038 & 0.024 & 0.119 & 0.056 & 0.314 & 0.208 & 0.028 & 0.016 & 0.17 & 0.076 \\
\hline Zakho & -0.085 & -0.130 & 0.223 & 0.060 & 0.090 & 0.048 & -0.229 & -0.126 & -0.032 & -0.011 \\
\hline Akre & -0.664 & -0.888 & -0.859 & -0.884 & -0.502 & -0.766 & -0.761 & -0.915 & -0.639 & -0.873 \\
\hline Amedy & -0.179 & -0.469 & -0.483 & -0.659 & -0.294 & -0.626 & -0.025 & -0.030 & -0.195 & -0.208 \\
\hline Mangesh & 0.307 & 0.160 & -0.709 & -0.485 & 0.061 & 0.031 & -0.219 & -0.122 & -0.529 & -0.106 \\
\hline Semel & -0.083 & -0.156 & -0.522 & -0.823 & -0.445 & -0.812 & 0.306 & 0.495 & -0.229 & -0.309 \\
\hline Zawite & -0.065 & -0.055 & -0.029 & -0.022 & 0.369 & 0.425 & 0.184 & 0.210 & 0.198 & 0.182 \\
\hline
\end{tabular}

The results of parametric linear regression ethod and nonparametric Mann-Kendall test in tables (3) and (4) were identical in all stations, excepting Semel station at spring season and Zawite station in annual series, $\mathrm{Z}$ value of Semel station in Spring season is zero means no trend and in annual for Zawite station is to week and the slope also have small value (-0.003); also for regression method this two station have low correlation coefficient ( $R$ value) thus these two stations Semel and Zawite in Spring season and Annual series respectively have no trend, otherwise the positive and negative trends were the same in both results. Duhok station has the same trend slop in annual series for both tables which is ( $\approx 0.08 \% /$ year), this increasing is due to the increasing of temperature and humidity of the region because Dohuk station is near to Duhok Dam. Also the annual results for Mangesh and Semel are similar for both methods as shown in above tables. Akre and Amedy stations have significant decreasing trend for summer series of both parametric and nonparametric methods. Most of trends are negative in both annual and seasonal for both methods, this implies that this decreasing in study area is due to increasing in temperature of northern part of Iraq (El-Sayed \& Al-Barzanji, 2013) (Al-Timimil \& Al-Khudhairy, 2018) .On the other hand, the results illustrated that the number of significant trends revealed by nonparametric test was less than of parametric method. Chiefly, the results of two methods were identical.

\section{CONCLUSION}

Time series of the seasonal and annual relative humidity were analyzed for seven stations located in Duhok province of Kurdistan region of Iraq. The parametric linear regression and nonparametric Mann-Kendall test have been used for data analyzing. The results showed that trends of relative humidity for annual series are negative except the Duhok station, which is illustrated increasing trend by $(0.07 \% / y e a r)$, this increasing in $\mathrm{RH}$ value is due to the Duhok Dam near the station because when temperature increased the rate of evaporation of water bodies ingresses more than the increasing in saturation vapor pressure of water, which is leading to increase in RH value of Duhok station. The significance trend was only at Mangesh station by $(-0.1 \% /$ year $)$. According to seasonal $\mathrm{RH}$, the 
significance trend was at Akre and Amedy in summer season about (-0.8\%/year and $0.6 \% /$ year) respectively. In general, most of water increases then the Relative humidity decreases. This study is useful to detect the availability of global warming in the study area. The increasing and decreasing of $\mathrm{RH}$ is due to the increasing in air temperature, the main factor that increase the temperature is greenhouse gases. Recently, the population of Duhok province increased heavily which causes the increasing in uses of local electric generators, cars, industries, Petroleum companies, factories, buildings and etc. the solution of this problem is to using renewable energy such as (Solar energy, Wind energy, geothermal energy and etc.), also using gases filters in factories and local electric generators, also using buses or bicycles instead of cars to reduce the greenhouse gases emission.

Acknowledgments: Thanks to the Directorate of meteorology and seismology of Duhok Province for giving the meteorological data of all stations in study area.

\section{REFERENCES}

Abdulwahab H.A. (2015) Analysis of Relative Humidity in Iraq for the Period 1951-2010. International Journal of Sciences Research Pub 5(5)

Abu-Taleb A. A., Alawneh A. J, Smadi M. M. (2007) Statistical Analysis of Recent Changes in Relative Humidity in Jordan. American Journal of Environment Sciences 3(2):75-77

Alshawaf A., Balidakis K., Dick G., Heise S. and Wickert J. (2017) Estimating trends in atmospheric water vapor and temperature time series over Germany. Atmosphere Measurement Technology 10: 3117-3132.

Al-Timimi Y. K., Al-Khudhairy A.A. (2018) Spatial and Temporal Temperature trends on Iraq during 1980-2015. IOP Conf. Series: Journal Physics Conference. Series 1003 (2018) 012091 doi:10.1088/17426596/1003/1/012091

Changnon S. A., Kunkel K. E., Reinke B. C. (1996) Impacts and responses to the 1995 heat wave: stations have negative trends, which are due to increasing in temperature, when the temperature tends to increase the saturation vapor pressure of a call to action. American Meteorology Society 77:1497-1506

Elliott W. P., Angell J. K. (1997) Variations of cloudiness, precipitable water and relative humidity over the United States: 19731993.Geophysic Resources Letter 24:41-44

El-Sayed M. R., Al-Barazanji Z. (2015) MannKendall trend analysis of surface air temperatures and rainfall in Iraq. Quarterly Journal of Hungarian Meteorology Series 119(4): 493-514

Gaffen D.J., Ross R. J. (1999) Climatology and trends of U.S. surface humidity and temperature. Journal of Climate 12:811-828

Hamed KH, Rao AR (1998) A modified MannKendall test for auto correlated data. Journal of Hydrology 204:182-196

Held I. M., Soden B. J. (2000) Water Vapor Feedback and Global Warming. Annual Review of Energy and the Environment. 25:441-475 doi.org/10.1146/annurev.energy.25.1.441

Huth R., Pokorna L.(2004) Parametric versus nonparametric estimates of climatic trends. Theoretical and Applied Climatology 77:107112

IPCC (2007) Climate change 2007: the physical science basis. Contribution of Working Group I to the Fourth Assessment Report of the Intergovernmental Panel on Climate Change. Cambridge University Press, Cambridge

Kousari M. R., Zarch M. A. (2010) Minimum, maximum, and mean annual temperatures, relative humidity, and precipitation trends in arid and semi-arid regions of Iran. Arab Journal of Geosciences 4:907-914. doi:10.1007/s12517-009-0113-6

Salmi T., Määttä A., Anttila P., Ruoho-Airola T., Amnell T. (2002) Detecting trends of annual values of atmospheric pollutants by the MannKendall test and Sen's slope estimates - the Excel template application MAKESENS. 
Publications on Air Quality No. 31, Report codeFMI-AQ-31.

http://www.fmi.fi/kuvat/MAKESENS_MANU AL.pdf. Accessed22June2012

Sen P. K. (1968) Estimates of the regression coefficient based on Kendall's tau. Journal of American Statement Association 63:13791389

Souch C., Grimmond S.B. (2004) Applied Climatology "'heat waves'. Programs in Physics and Geography. 28: 599-606.

Tabari H., Marofi S. (2011) Changes of Pan Evaporation in the west of Iran. Water Recourse Management 25: 97-111.

Talaee P. H., Sabziparvar A. A., Tabari H. (2012) Observed changes in relative humidity and dew point temperature in coastal regions of Iran. Theoretical and Applied Climatology 110:385-393. doi:10.1007/s00704-012-0630-1

Van Wijngaarden W. A., Vincent L. A. (2003) Trends in relative humidity in Canada from
1953-2003. Report prepared for Climate Research Branch, Meteorological Service of Canada.

Wilcox RR (1998) A note on the Theil-Sen regression estimator when the regressor is random and the error term is heteroscedastic. Biom J 40:261-268

Willett K. M., Gillett N. P., Jones P.D., Thorne P.W. (2007) Attribution of observed surface humidity changes to human influence. Nature 449:710-713

Xia Y., Fabian P., Stohl A., Winterhalter M. (1999) Forest climatology: estimation of missing values for Bavaria, Germany. Agricultural Fore Meteorology 96: 131-144

Zhang Q., Xu C. Y., Zhang Z., Chen Y. D. (2009) Changes of temperature extremes for 19602004 in Far-West China. Stosch Environ Res Risk

Assess

23(6):721-735 